\title{
Educating the Senses: Explorations in Aesthetics, Embodiment and Sensory Pedagogy
}

\author{
Sharon Todd ${ }^{1} \cdot$ Marit Honerød Hoveid $^{2}$ (D) Elisabet Langmann ${ }^{3}$
}

Accepted: 27 March 2021 / Published online: 23 April 2021

(c) The Author(s), under exclusive licence to Springer Nature B.V. 2021

\begin{abstract}
This volume takes two different, albeit intertwined approaches. The first concerns a reformulation of aesthetics in education-one which highlights the sensory dimensions of educational experience. The second concerns a turn to the body and the senses as that which is deeply involved in practices of teaching and learning.
\end{abstract}

Keywords Senses $\cdot$ Body $\cdot$ Embodyment $\cdot$ Aestethics $\cdot$ Living

This Special Issue was conceived long before the word COVID became part of our daily lexicon. We thought even then (way back in 2018!) that the sensory aspects of education were under theorized, if not downright forgotten, in the increasingly performative cultures that mark educational institutions at all levels as well as in contemporary theoretical framings of education. The pandemic's presence in our lives has occasioned a series of difficult adjustments around the globe, both personally and educationally, that none of us could have foreseen and which has only served to increase our sensitivity to the issues we identified earlier. For instance, because the virus is transferred through social contact, we have been compelled to minimize social encounters, largely avoiding physical meetings, shaking hands, hugging one another, and travelling to meet family, colleagues and friends. Educational institutions have been heavily affected by the lack of physical social contact as students of all ages have been sent into various forms of educational isolation, excluding them from the regular bodily interactions and material conditions that comprise everyday life in schools, universities and other educational settings. Teaching has moved onto digital

Marit Honerød Hoveid

marit.hoveid@ntnu.no

Sharon Todd

Sharon.Todd@mu.ie

Elisabet Langmann

elisabet.langmann@sh.se

1 Department of Education, Centre for Public Education and Pedagogy, Maynooth University, Kildare, Ireland

2 Department of Education and Lifelong Learning, Norwegian University of Science and Technology, Trondheim, Norway

3 School of Culture and Education, Södertörns Högskola, Huddinge, Sweden 
platforms and on-line instruction has in many quarters become the norm. The kind of presence individuals experience in the digital classroom is obviously different from that experienced when we are in the same room with physical others. The speaking into a camera, the image flickering on the screen, a turned off video, a muted microphone-all of this highlights the social and physical distance between us. This is not to say that teachers have not been creative in developing active forms of discussion and engagement between students in order to bridge this distance. Indeed, they have. Yet, what the pandemic has pointed up is that no matter which platforms, technologies, or methods are used, there remains a physical gap built into our on-line pedagogies that has never been present on such a vast scale before. Nonetheless, while the pandemic has exacerbated this gap most dramatically, the reason for this Special Issue lies in what we perceived had been a lack of attention paid to the senses, in all their complexity, within educational theory long prior to this.

Thus, we view this Special Issue as addressing itself directly to the educational concerns of physical distance raised in such a pointed way by the present situation, while simultaneously highlighting the living body and the senses as central to the very idea and project of education itself. Specifically, the volume conceptualizes how the sensory and embodied aspects of the human condition can be acknowledged in actual processes of teaching and learning. As a challenge to instrumental accounts of education, which tend to focus on narrow views of cognition and acquisition of information, scholars within philosophy of education have long sought to expand the concept of education by exploring alternative or forgotten aspects of teaching and learning. Some instances of this include a reframing of the purpose of education in terms of the oft-times forgotten dimension of subjectification (Biesta 2014; Ruitenberg 2013), and a rethinking of teaching that recalls the importance of being attentive in the present (Masschelein and Simons 2013). However, even within these important and recent interruptions into the field, there is scant attention paid to the embodied and lived experiences of teachers and students without which education makes little sense $^{1}$ - after all we do not live in the heads we see on our screens. How do we theorize a view of education as a lived, perceived, and embodied experience of sensing the world and ourselves in the present? And in what ways does the lived specificity of educational encounters generate a different set of pedagogical questions for contemporary educational theory?

By way of response, this volume takes two different, albeit intertwined approaches. The first concerns a reformulation of aesthetics in education - one which highlights the sensory dimensions of educational experience. The second concerns a turn to the body and the senses as that which is deeply involved in practices of teaching and learning.

\section{Aesthetics in/of Education}

Aesthetics is so frequently thought of as a theory or philosophy of art, and when spoken about in relation to education it is often concerned with various types of art-based practices. The work of John Dewey, Maxine Greene and Elliot Eisner are germane here, particularly as they sought, in their distinctive ways, to inquire into what education had to learn from art and the experiences it offers. ${ }^{2}$ While seeing their work as significant for

\footnotetext{
1 There have been some forays into this area. See Todd (2016), Probyn (2004), Hoveid (2012), Bergdahl and Langmann (2018).

2 See also the essays in Lewis and Laverty (2015).
} 
opening education toward a more humane and creative practice, we take another approach to aesthetics here. Instead, we invite within these pages a different formulation, returning to the original Greek meaning of aesthetics or aisthetikos as a specific engagement with the senses: from aistheta "perceptible things" and from aisthesthai "to perceive" (https:// www.etymonline.com/word/aesthetic). In so doing, the papers collectively aim to extend the understanding of the relation between aesthetics and education by exploring pedagogy as a particular, sensuous and embodied encounter with the world. Our attempt is not simply to "theorise" about bodies and senses in general, but to elucidate the importance of what Elspeth Probyn (2004) refers to as the singular "live body" in education more specifically.

From this point of view, the aesthetic dimensions of education are primarily concerned with how our living perceptions shape how it is we come to experience the world, ourselves and each other. Although one might explore these perceptions through various types of art practices (and indeed, art does offer unique modes of engagement in this regard), our point here is to underline the aesthetic nature of education itself. That is, it is to see that our everyday pedagogical practices are dependent on some form of sensory engagement, be this through visual, auditory, olfactory, tactile or gustatory encounters. Indeed, aesthetics is not simply something we find 'in' education, but it constructs the very basis upon which the dynamics of teaching and learning are made possible. For instance, learning to read requires being taught to see words, to hold a book and turn a page, and often to trace a line of text with one's finger; thus teaching requires a sensitivity to the complex aesthetics of perceptions and bodily actions necessary to what we usually conceive as a predominantly intellectual exercise. On another level, aesthetics is about educating the senses in ways that can promote discernment (teaching a young child not to eat glue despite its possible tastiness); refinement (a student's sense of touch on guitar strings); and engagement (participation based on listening carefully to what another student is saying). Aesthetics in this way is embedded in our practices as teachers and students in order to come to know, make meaning, and question. Even on-line environments evoke the senses, albeit in a potentially more limited way than in actual physical settings such as classrooms, where shared objects of smell, sound, touch and sight mark a form of "withness" and collectivity. Viewing the aesthetic dimensions of education in this way allows us to delve more deeply into the ways teaching itself becomes an aesthetic practice.

\section{Senses and Embodiment in Education}

As most teachers and educators know, the use of eyes, mimicry, intonation of voice, gestures, and bodily movements is an integral part of educational practice, as well as a powerful tool for setting the tone of a lesson, conveying nonverbal messages between teachers and students, and for managing social and pedagogical interactions in the classroom more generally. In this sense, educational practice is always already embodied and multisensorial. Experienced teachers easily sense whether the students are ready to begin a lesson or not by establishing eye contact; a subtle nod with the head can invite a shy student to engage in a classroom discussion and a raised hand can stop someone from expanding a thought. Bodily and sensory expressions are also used to check that the students understand the subject matter or are being attentive; the sound of whispering and sighs can quickly tell the teacher if the students are becoming bored or lost; a puzzled facial expression indicates that something needs to be repeated or revised. While it seems difficult, if not impossible, to understand pedagogical practice without including sensory and bodily experiences, what 
characterizes the ideal "pedagogical sensescape" of the classroom has varied throughout history. Following David Howes's anthropological definition, different pedagogical sensescapes have been shaped" by the particular mode of distinguishing, valuing and combining the senses in the culture under study" (2005, p. 143). The familiar optics and acoustics of the silent, motionless and attentive classroom, for example, have been challenged by more vibrant pedagogical soundscapes both past and present, and the relation between sound and silence, motion and stillness, visibility and invisibility have played a central role in characterizing the sensory world of schooling (Landahl 2019). While historians of education have explored how teacher-student interactions have been regulated and controlled at different times in history from a sensorial perspective, the increasing use of digital learning platforms and on-line classrooms has forced many of us to become more attentive to the meaning and place of our own bodily and sensory experiences in education. Within educational theory and research, there has also been a growing interest in the interdisciplinary fields of embodied cognition, sensory studies, and embodied education. Arising from a number of philosophical and theoretical strands, the "carnal turn" (Sheets-Johnstone 2009) within the humanities and social sciences has influenced the way some educational researchers have reconsidered the relation between mind and body in educational experiences, suggesting a more nuanced understanding of how people interact as living bodies in concrete educational surroundings. The classroom then, is not just a place which "accommodates" bodies, but a place that is itself experienced through an embodied and multisensorial mode of being in the world. What this theoretical interest in the living and sensing body as an essential part of educational practice can offer philosophers of education, we suggest, is a renewed focus on how we make sense of our life in the flesh (in the double sense of sensation and meaning), as well as on the pedagogical implications of embodiment in education. To have the eye, the ear, or the touch of a teacher, then, is neither about pure cognition nor about pure sensation, but about learning how to read and interpret the sensory and bodily dimensions of educational practice more wisely (Kearney 2015).

\section{The Contributions}

The senses and bodily experiences, as this issue demonstrates, are essential for a living educational practice and, thus, it is crucial to explore embodied and sensory dimensions of teaching and learning in ways that go beyond and dig deeper into our present understandings of education. The papers seek to address the following overall questions: What is specifically educational about one's embodied and sensory encounters with the world? And how might such encounters reconfigure dominant practices of education? In responding to these questions, the authors draw on different philosophical strands such as philosophical pragmatism, phenomenology of the body, sensory studies, and process philosophy. Taken together, the different theoretical perspectives represented in the special issue offer a nuanced and multilayered contribution to what it means to engage in educational practices as living, embodied and sensing beings.

Becoming a subject by attending to sensory experiences in and through education is at the heart of Sharon Todd's argument. Encounters of touch, she suggests, point to fundamental levels of interaction. Todd argues that human bodies are not just in but "of encounters, of relation". Life forms are diverse, and movements across boundaries through touch is elementary, she argues. There is an "outside" and an "inside" to both humans and others which are porous; thus, being of encounters points to an intrinsic sense of spatiality and 
movement. The affective region of touch is her particular interest in this-by pointing to the sense of touch she helps us see the complexity of human and other than human interaction, especially relevant in educational encounters. A sensuous education according to Todd "therefore has a threefold task: to acknowledge the sensory elements of everyday life as important to meaning and knowledge; to engage in sensory strategies and experiments; and to attend to the felt sensation students experience and make them central to our very practices of study and inquiry".

The idea that human flourishing lies at the heart of liberal education informs the next paper. Here, Christine Doddington argues that "social life in a community is a necessary condition for complete flourishing as a human being". In her article she discusses human flourishing and aesthetic experience as "any form of sense or soma-based experience which therefore includes, but also extends beyond, experience in art." For her the educational point is to create conditions in education where interactions between teachers and students, as a community, establish forms of communication that go beyond competitive performance and that point to what connects us and to meaning making processes between teachers and students.

The act of drawing challenges the one who draws but "also the closure of the world formation", Nancy Vansieleghem argues. Her project is to reclaim drawing as a cornerstone for education, by pushing the "significance of the act of drawing towards the existential side of the spectrum". She points to drawing, framed as "a faculty of making sense and letting sense be formed", as a way of opening oneself to the outside. Thus, a child's drawing is seen as a way of reaching out to the world, as a way of making an impression upon something. And she argues "that the central stake is not to draw something but to notice things among the millions of other things that are present to our senses, and a value to unexpected sensations and feelings. Hence, it is attention itself (as sensing) which is the aim of the conduct of drawing". This aim, then, is a way of demonstrating aesthetics in education. In this the threefold task of education proposed by Todd (this issue) means that formation of subjectivity continually needs re-shaping. Vansieleghem argues that what is at stake for pedagogy is to arrive at a condition where one's subjectivity is challenged and where there is an "opening for experiencing the world once more".

Children experience the world through their bodies, and the younger they are, the more present their bodily sensing and their expressions of sensing is. Relations of time, phenomenological time and chronological time, suspension and breath, are discussed by Tanu Biswas in reference to children and adults in pedagogical relations. The child as a default addressee of pedagogy is challenged. By attending to how children experience the world, the adult has a possibility for "experiencing the world once more." Her project is however even more critically astute. She points to the state in which we (humans) currently find ourselves and describes it as an overheated world bound to an acceleration of change, drawing on the Norwegian anthropologist Thomas Hylland Eriksen (2016). In this sense, being re-taught to experience time - by slowing down and attending to breath of/with an infant-lets one experience another rhythm, another time than that of ordered clock-time. Also, phenomenological time opens other ways of experiencing and understanding one's environment. Embodied encounters between teacher and student(s)/adult and child(ren) incorporate in them possibilities for lived experiences that challenge the taken for granted. Once conceptualisations are made, they tend to stiffen, thus being able to unstiffen adults "conceptual muscles" is part of Biswas project—in this, children can be the teachers.

And perhaps also dogs. Marit Honerød Hoveid uses her experiences from dogmushing as grounds for a discussion on teaching. As is seen in several of the articles of this special issue, the authors are concerned with educational practices that are rich in terms 
of bringing life to education, so that human flourishing, human subjectivity and re-experiencing of the world is possible. Like Doddington, Hoveid is concerned with the practice of teaching (and learning) as a space for experiencing participation and collaboration between students and teachers. By pointing to the way human bodies and dogs sense their environment in dogmushing, and how this way of sensing informs and frames human memory, she points to the vitality of sensing in education. Experiencing life is bound to sensory experiences, and this is what we (as editors) want to underscore as a basic requirement in all forms of education, that sensory experiences should be built into ways of theorising and practicing all educational processes.

\section{References}

Bergdahl, Lovisa, and Elisabet Langmann. 2018. Pedagogical Postures: A Feminist Search for a Geometry of the Educational Relation. Ethics and Education 13(3): 309-328.

Biesta, Gert JJ. 2014. The Beautiful Risk of Education. Boulder, CO: Paradigm.

Eriksen, Thomas H. 2016. Overheating: An Anthropology of Accelerated Change. London: Pluto Press.

Hoveid, Marit H. 2012. A Space for 'Who'-A Culture for 'Two': Speculations Related to an 'In-Between Knowledge.' Ethics and Education 7(3): 251-260.

Howes, David, ed. 2005. Empire of the Senses: The Sensual Culture Reader. Oxford: Berg.

Kearney, Richard. 2015. The Wager of Carnal Hermeneutics. In Carnal Hermeneutics, ed. R. Kearney and B. Treanor, 15-56. New York: Fordham University Press.

Landahl, Joakim. 2019. Learning to Listen and Look: The Shift from the Monitorial System of Education to Teacher-Led Lessons. The Senses and Society 14(2): 194-206.

Lewis, Tyson, and Megan Laverty, eds. 2015. Art's Teaching, Teaching's Art. Dordrecht: Springer.

Masschelein, Jan, and Maarten Simons. 2013. In Defence of the School: A Public Issue. Leuven: Education, Culture and Society Publishers.

Probyn, Elspeth. 2004. Teaching Bodies: Affects in the Classroom. Body \& Society 10(4): 21-43.

Ruitenberg, Claudia. 2013. The Double Subjectification Function of Education: Reconsidering Hospitality and Democracy. In Education and the Political: New Theoretical Articulations, ed. T. Szkudlarek, 89-105. Rotterdam: Sense.

Sheets-Johnstone, Maxine. 2009. The Corporeal Turn: An Interdisciplinary Reader. Exeter: Imprint Academic.

Todd, Sharon. 2016. Education Incarnate. Educational Philosophy and Theory 48(4): 405-417.

Publisher's Note Springer Nature remains neutral with regard to jurisdictional claims in published maps and institutional affiliations. 